\title{
DINAMIKA IMPLEMENTASI KEBIJAKAN KONSERVASI LAHAN TAMAN NASIONAL BROMO TENGGER SEMERU
}

\section{THE DYNAMICS OF BROMO TENGGER SEMERU NATIONAL PARK LAND CONSERVATION POLICY IMPLEMENTATION}

\author{
Wimmy Haliim \\ Fakultas Ilmu Sosial dan IImu Politik, Universitas Brawijaya. \\ Jl. Veteran-Kota Malang \\ Email:wimmyfisip@ub.ac.id
}

Naskah diterima: 7 Maret 2017; revisi terakhir: 9 April 2018; disetujui: 11 April 2018

\begin{abstract}
The existence of Bromo Tengger Semeru National Park(TN.BTS) is very important to preserve the flora and fauna and its ecosystem. In addition, TN.BTS also has a role to support research, education, recreation and cultivation activities. Inside the TN.BTS there is an enclave village named Ranu Pani. Problems arise when the villagers cut down trees causing negative impacts in certain areas and tourist areas management, which potentially cause damage to valuable sites of the Tengger community. By using descriptive method, this research tries to see how the role of $B B$-TN.BTS in solving the problem. The research concludes that efforts to empower the BB-TN.BTS and Tengger community should always be actively prioritizedin preserving the National Park area. Empowerment means to involve Tengger indigenous people actively in planning, implementation, beneficiary, as well as in the process of monitoring and evaluation of TN.BTS management.
\end{abstract}

Keywords: Soil Conservation, National Policy and Active Empowerment

\begin{abstract}
Abstrak
Keberadaan Taman Nasional Bromo Tengger Semeru (TN.BTS) sangat penting untuk menjaga proses pelestarian flora dan fauna serta keseimbangan ekosistemnya. Selain itu, keberadaan TN.BTS juga memiliki peran untuk mendukung kegiatan penelitian, pendidikan, rekreasi dan budidaya. Namun di sisi lain, masyarakat Tengger, terutama desa Ranu Pani adalah sebuah desa enclaveyang ada di kawasan TN.BTS. Fokus penelitian ini adalah di Balai Besar Taman Nasional Bromo Tengger Semeru (BBTN.BTS). Konservasi Tanah TN.BTS menjadi bermasalah ketika masyarakat Tengger
\end{abstract}


menebang pohon, menimbulkan dampak negatif di beberapa tempat, dan pengelolaan kawasan wisata, yang berpotensi menyebabkan kerusakan situs-situs berharga masyarakat Tengger. Dengan menggunakan metode penelitian deskriptif, peneliti mencoba melihat bagaimana peran BB-TN.BTS dalam menyelesaikan masalah kebijakanpemerintah melalui BB-TN.Upaya pemberdayaan BB-TN.BTS dan masyarakat Tengger secara aktif dalam melestarikan kawasan Taman Nasional perlu selalu diprioritaskan. Pemberdayaan juga berarti secara aktif melibatkan masyarakat adat Tengger dalam perencanaan, pelaksanaan, penerimaan manfaat, juga dalam proses monitoring dan evaluasi pengelolaan TN.BTS.

Kata kunci: Konservasi Tanah, Kebijakan Nasional dan Pemberdayaan Aktif

\section{A. PENDAHULUAN}

Salah satu taman nasioanal di Jawa Timur adalah Taman Nasional Bromo Tengger Semeru (TN.BTS). Keberadaan Taman Nasional Bromo Tengger Semeru sangat penting untuk menjaga proses pengawetan flora dan fauna serta keseimbangan ekosistemnya. Selain itu, keberadaan Taman Nasional Bromo Tengger Semeru juga memiliki peran untuk menunjang kegiatan penelitian, pendidikan, rekreasi dan budidaya. Taman Nasional Bromo Tengger Semeru menjadi Taman Nasional pada tanggal 14 Oktober 1982. Menurut surat pernyataan Menteri Agraria Nomor 736 / X / 1982., dengan daerah yang luas 50.000 Ha yang menjadi Taman Nasional. Kemudian pada tanggal 23 Mei, 1997 Menteri Agraria mengeluarkan Surat Keputusan Nomor: 278 / KptsVI / 1997 tentang menandakan penunjukan daerah luas 50.276,20 Ha sebagai Taman Nasional Bromo Tengger Semeru (East Java Departement of Tourism, art and Culture Service, 2000).

Beberapa alasan pemerintah membentuk TN.BTS, bahwa daerah taman nasional memiliki berbagai jenis flora dan fauna yang beragam. Lebih dari pada itu, di daerah TN.BTS juga memiliki beberapa sumber air yang sangat penting bagi Jawa Timur. Salah satunya adalah Sumber Umbulan. Sumber Umbulan adalah sumber air yang paling besar di Jawa Timur dan adalah terletidak di Bawah Gunung Bromo. Sumber Umbulan memiliki air yang berada di lautan pasir Bromo dan berada di kawasan TN.BTS. Selain itu, penggunaan sumber air tersebut adalah sumber bagi kegiatan perindustrian, misalnya yang digunakan Pabrik Gula Kedawung serta perusahan penetesan Tambak terletak di daerah pantai lautan Jawa. Sumber Air yang berada di TN.BTS juga merupakan sumber air bagi beberapa Industri kepariwisataan, dan pertanian di Jawa Timur (Profil Taman Nasional Bromo Tengger Semeru, 2010).

Taman Nasional Bromo Tengger Semeru dikelola oleh Balai Taman Nasional Bromo Tengger Semeru. Tugas Balai Taman Nasional Bromo Tengger Semeru adalah untuk pengelolaan, konservasi dan pelestarian tumbuh-tumbuhan, marga satwa dan perlindungan ekosistem Taman Nasional. Petugas Balai sering menghadapi banyak masalah, dan masalah yang paling besar adalah penggunaan tanah yang ilegal. Penggunaan tanah ilegal bukan saja mengancam Taman Nasional Bromo Tengger Semeru saja tetapi mengancam kehidupan masyarakat dan industri di Jawa Timur (Nugroho, 2016).

Struktur dan organisasi kantor Balai Taman Nasional memiliki komposisi yang sangat baik dan tidak terlalu kompleks. Struktur Balai Taman Nasional Bromo Tengger Semeru memiliki tingkat hierarkis yang sangat jelas dan langsung. Struktur ini tidak ada masalah dengan departemendeparteman pemerintahan yang lainnya. Hal tersebut sangatlah penting bagi struktur dan organisasi. Hierarki dan organisasi yang sehat tentu saja bisa memaksimalkan kerja mereka untuk mengelola Taman Nasional Bromo Tengger Semeru seluas 50.276,20 Ha dan terletidak dalam empat Kabupaten. Kabupaten yang termasuk TN.BTS adalah: Kabupaten Probolingo, Kabupaten Malang, 
Kabupaten Pasuran dan Kabupaten Lumajang, semuanya terletak di Propinsi Jawa Timur (Surat Keputusan Menteri Kehutanan Nomor: 6186/Kpts-II/2002).

Taman Nasional Bromo Tengger Semeru meliputi tiga Wilayah. Wilayah Satu termasuk Kabupaten Pasuruan serta Kabupaten Probolinggo. Wilayah Dua adalah Kabupaten Lumajang. Ketiga, adalah Wilayah Malang. Setiap Wilayah mempunyai Kantor Seksi Wilayah dan di bawah setiap Kantor Seksi adalah beberapa Resort Konservasi Wilayah (Surat Keputusan Menteri Kehutanan Nomor: 178/Menhut-II/2005).

Kegiatan pengelolaan Taman Nasional Bromo Tengger Semeru sampai saat ini masih menghadapi berbagai masalah. Masalah tersebut disebabkan oleh tiga jenis penyebab utama, yaitu tingkat pengelolaan, keadaan sosial ekonomi dan kesadaran masyarakat yang menimbulkan munculnya permasalahan berupa perambahan kawasan hutan taman nasional, perburuan satwa tanpa ijin, pencurian tanaman yang dilindungi, penebangan tanpa ijin, pengambilan kayu bakar, sampah, dan tumpang tindih peruntukan kawasan (Profil Taman Nasional Bromo Tengger Semeru, 2010). Salah satu permasalah pengelolan TN.BTS berada di Desa Ranu Pani. Data Taman Nasional Bromo Tengger Semeru di Resort Ranu Pani tidaksiran minimum pengambilan kayu bakar di Desa Ranu Pani pada tahun 2010-2011 mencapai 110-meter kubik perhari untuk 371 kepala keluarga (Dendang, 2016). Desa Ranu Pani merupakan desa enclave (desa yang berada di dalam kawasan taman nasional) yang ada di Taman Nasional Bromo Tengger Semeru (Budiyanti, 2015). Masyarakat Desa Ranu Pani sebagian besar mata pencaharianya adalah petani dan pencari kayu bakar untuk memenuhi kebutuhan sehari-hari.

\section{B. METODE PENELITIAN}

Penelitian ini termasuk dalam jenis penelitian deskriptif dengan menggunakan pendekatan kualitatif. Fokus penelitian ini adalah di Balai Besar Taman Nasional Bromo Tengger Semeru (BBTNBTS), dimana nantinya akan dapat disimpulkan bagaimanakah implementasinya yang dirinci sebagai berikut:

1. Melihat dinamika konservasi lahan antara BB-TNBTS dengan masyarakat Tengger, Khususnya warga Desa Ranu Pani;

2. Melihat Bagaimana BB-TNBTS menyelesaikan konflik dengan Warga Tengger terkait konservasi lahan.

Kemudian, lokasi penelitian adalah Taman Nasional Bromo Tengger Semeru dan yang menjadi situs penelitian adalah Balai Besar Taman Nasional Bromo Tengger Semeru. Lalu sumber data penelitian ini adalah sumber data utama dalam penelitian kualitatif ialah kata-kata, tindakan selebihnya adalah data tambahan seperti dokumen dan lain-lain (Moleong, 2002:112). Sehingga sumber data yang digunakan dalam penelitian ini adalah wawancara terhadap pelaksanan Kebijakan Konservasi Lahan di daerah TNBTS serta dokumen-dokumen yang berhubungan dengan pelaksanaan Kebijakan Konservasi Lahan di daerah TNBTS.

Dalam penelitian ini, peneliti menggunakan model interaktif dari Miles dan Huberman untuk menganalisis data hasil penelitiandengan komponen sebagai berikut: (Miles, Huberman, dan Saldana, 2014:12)

1. Data Condensation (Kondensasi Data)

2. Data Display (Penyajian Data)

3. Conclusion Drawing/Verifying (Menarik Kesimpulan/Verifikasi) 


\section{KERANGKA TEORI}

Artikel ini akan membahas terkait Dinamika Implementasi Kebijakan Korservasi Lahan TN.BTS, jadi akan menggunakan teori-teori terkait implementasi kebijakan. Implementasi kebijakan merupakan aktifitas atau usaha-usaha yang dilaksanakan untuk melaksanakan semua rencana dan kebijaksanaan yang telah dirumuskan dan ditetapkan dengan dilengkapi segala kebutuhan (Syukur, 1987:402). Implementasi kebijakan pada prinsipnya adalah agar sebuah kebijakan yang melatarbelakangi program tersebut dapat mencapai tujuannya. Tidak kurang dan tidak lebih. Korten dalam Andersen (1997:12), menyatakan bahwa suatu kebijakan akan berhasil dilaksanakan jika terdapat kesesuaian dari tiga unsur implementasi program, yaitu: (1) kesesuaian antara program dengan pemanfaat. (2) kesesuaian antara program dengan organisasi pelaksana. (3) kesesuaian antara kelompok pemanfaat dengan organisasi pelaksana.

Kemudian, implementasi kebijakan dalam konteks kebijakan publik terdiri dari beberapa tahap yaitu: (a) Merancang bangun (design) program beserta perincian tugas dan perumusan tujuan yang jelas, (b) Melaksanakan (application) program dengan mendayagunakan struktur-struktur dan personalia, dana serta sumber-sumber lainnya. (c) Membangun sistem penjadwalan, monitoring dan sarana-sarana pengawasan yang tepat guna serta evaluasi (hasil) pelaksanaan (Tachjan, 2006:35).

Kita dapat melihat beberapa kriteriadalam penilaian apakah sebuah proses implementasi kebijakan telah berjalan dengan baik, memperhatikan beberapa faktor diantaranya yakni: (1)Apakah organisasi pelaksana teknis telah disiapkan? (2) Apakah pelaksana program sudah mengerti akan rencana, sasaran, dan tujuan kebijakan? (3) Apakah para aktor yang telah ditetapkan dan siap menerima tanggung jawab pelaksanaan program tersebut? (4) Apakah koordinasi antara pelaksana program telah dilakukan dengan baik? (5) Apakah kewajiban dan hak, telah diberikan dan dipahami serta dilaksanakan dengan baik oleh pelaksana kebijakan? (6) Apakah kriteria penilaian keberhasilan program sudah ada, jelas, dan diterapkan dengan baik oleh pelaksana program? (Esmara, 2010; 43)

Indonesia secara umum masih menganut model implementasi Continentalist, model kebijakan tersebut menjelaskan bahwa kebijakan publik harus memiliki kebermanfaat bagi penerimanya. Model implementasi suatu kebijakan tersebut dapat digambarkan sebagai berikut:

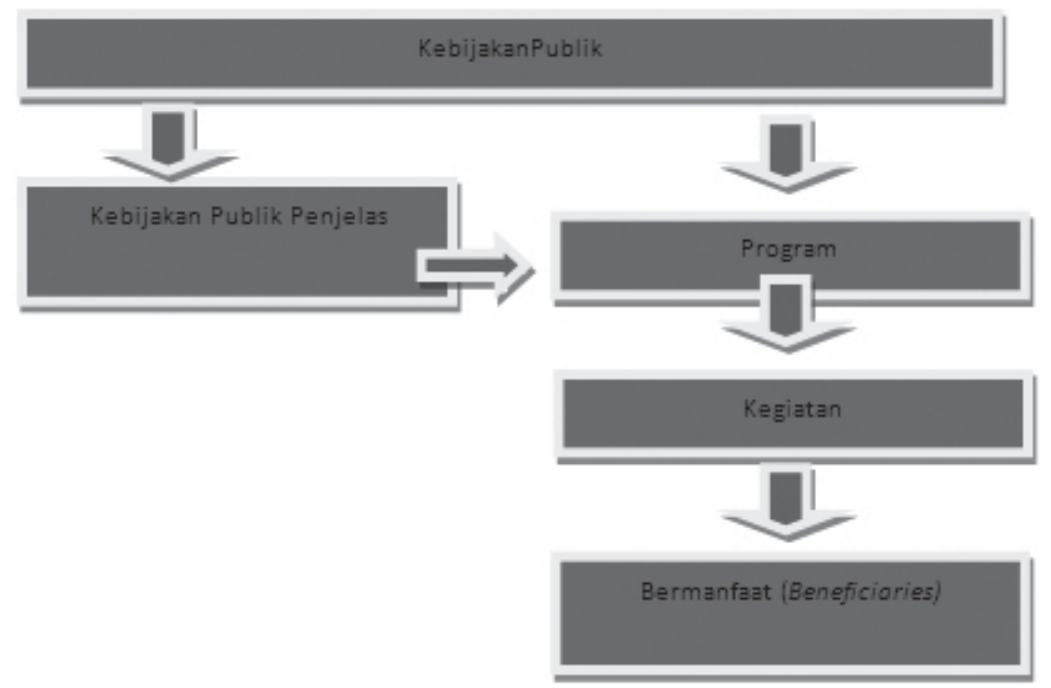

Sumber: Nugroho (2014:657)

Gambar 1.

Implementasi Kebijakan Continentalist 
Salah satu model implementasi program yakni model yang diungkapkan oleh Korten dalam Andersen (1997). Model ini memakai pendekatan proses yang lebih dikenal dengan model kesesuaian implementasi program. Model kesesuaian Implementasi Program Korten digambarkan sebagai berikut:

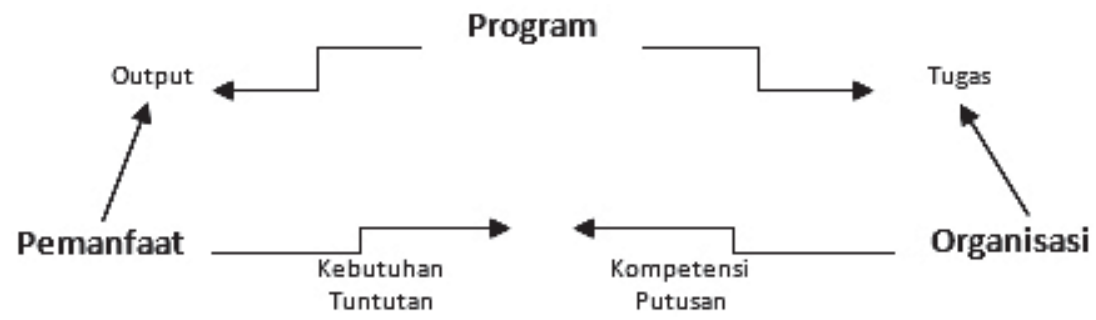

Sumber: Korten (dalam Andersen, 1997)

Gambar 2.

Implementasi Program

Korten menggambarkan model ini berintikan tiga elemen yang ada dalam pelaksanaan program yaitu program itu sendiri, pelaksanaan program, dan kelompok sasaran program. Korten dalam Andersen (1997:12), menyatakan bahwa suatu programakan berhasil dilaksanakan jika terdapat kesesuaian dari tiga unsur implementasi program, yaitu:

a. Pertama, kesesuaian antara program dengan pemanfaat, yaitu kesesuaian antara apa yang ditawarkan oleh program dengan apa yang dibutuhkan oleh kelompok sasaran (pemanfaat).

b. Kedua, kesesuaian antara program dengan organisasi pelaksana, yaitu kesesuaian antara tugasyang disyaratkan oleh program dengan kemampuan organisasi pelaksana.

c. Ketiga, kesesuaian antara kelompok pemanfaat dengan organisasi pelaksana, yaitu kesesuaian antara syarat yang diputuskan organisasi untuk dapat memperoleh output program dengan apa yang dapat dilakukan oleh kelompok sasaran program.

Berdasarkan pola yang dikembangkan Korten, dapat dipahami bahwa kinerja program tidak akan berhasil sesuai dengan apa yang diharapkan kalau tidak terdapat kesesuaian antara tiga unsur implementasi kebijakan. Hal ini disebabkan apabila:

a. Output program tidak sesuai dengan kebutuhan kelompok sasaran, jelas output tidak dapat dimanfaatkan

b. Jika organisasi pelaksana program tidak memiliki kemampuan melaksanakan tugas yang disyaratkan oleh program, maka organisasinya tidak dapat menyampaikan output program dengan tepat.

c. Jika syarat yang ditetapkan organisasi pelaksana program tidak dapat dipenuhi oleh kelompok sasaran, maka kelompok sasaran tidak mendapatkan output program.

Atas penjelasan diatas, penulis mempunyai maksud dan tujuan dalam penulisan artikel ini untuk memberikan solusi yang bisa digunakan untuk menyelesaikan permasalahan terkait implementasi kebijakan konservasi lahan Taman Nasional Bromo-Tengger-Semeru.

Penelitian ini juga menggunakan penelitian terdahulu didalam pelbagai jurnal untuk menambah kekayaan wawasan, pengetahuan dan informasi peneliti serta membedakan penelitian ini dengan penelitian terdahulu. Penjelasannya sebagai berikut: 
Tabel 1.

Penelitian Terdahulu dan Kontribusinya terhadap artikel ini.

\begin{tabular}{|c|c|}
\hline & Kontribusi Penelitian \\
\hline $\begin{array}{l}\text { Astriyantika, M. (2016). Studi Konservasi } \\
\text { Sumberdaya Alam Hayati pada Masyarakat } \\
\text { Tengger di Resort Ranu Pani, Taman } \\
\text { Nasional Bromo Tengger Semeru. Media } \\
\text { Konservasi, } 19(1) \text {. }\end{array}$ & $\begin{array}{l}\text { Peneliti mendapatkan informasi terkait } \\
\text { perkembangan TNBTS dari waktu ke } \\
\text { waktu. Perbedaannya dengan penelitian } \\
\text { ini adalah, penelitian Astriyantika hanya } \\
\text { tentang konservasi Sumberdaya alam } \\
\text { saja. }\end{array}$ \\
\hline $\begin{array}{l}\text { Budiyanti, S. (2015). Analisis Deskriptif } \\
\text { Aaktifitas dan Potensi Komunitas Desa } \\
\text { 'Enclave' Ranu Pani PadaZona Pemanfaatan } \\
\text { Tradisional, Kecamatan Senduro, Kab. } \\
\text { Lumajang, Wilayah Taman NasionalBromo } \\
\text { Tengger Semeru (TNBTS). DIMENSI, 8(2). }\end{array}$ & $\begin{array}{l}\text { Peneliti mendapatkan informasi terkait } \\
\text { kegiatan dan tradisi masyarakat desa } \\
\text { Ranu Pane. Perbedaannya, penelitian ini } \\
\text { melihat bagaimana dampak tradisi } \\
\text { mereka dalam menyikapi kebijakan yang } \\
\text { diterapkan pemerintah. }\end{array}$ \\
\hline $\begin{array}{l}\text { Setiawan, I. (2012). PEREMPUAN DI } \\
\text { BALIK KABUT BROMO: Membaca Peran } \\
\text { Aktif Perempuan Tengger dalam Kehidupan } \\
\text { Rumah Tangga dan Masyarakat. Jumal } \\
\text { Humaniora, 20(2), 136-148. }\end{array}$ & $\begin{array}{l}\text { Peneliti mendapatkan informasi terkait } \\
\text { peran aktif perempuan tengger dalam } \\
\text { kehidupan sehari-hari. Sehingga } \\
\text { menambah pengetahuan penulis terkait } \\
\text { kehidupan masyarakat tengger. }\end{array}$ \\
\hline 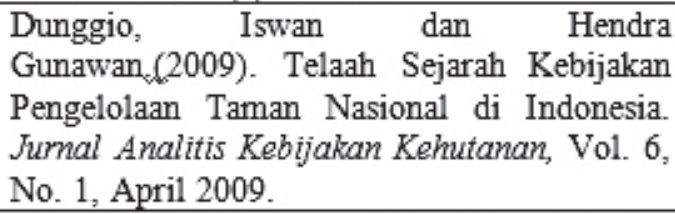 & $\begin{array}{l}\text { Penelitian tersebut penting bagi } \\
\text { penelitian ini, karena memberikan } \\
\text { informasi serta pengetahuan bagi peneliti } \\
\text { dalam mengetahui perkembangan } \\
\text { kebiakan TNBTS dari waktu ke waktu. }\end{array}$ \\
\hline $\begin{array}{l}\text { Faridah, Ika F. (2013). Toleransi Antarumat } \\
\text { Beragama Masyarakat Perumahan. Jumal } \\
\text { Komunitas, Vol 5, No 1, 51-69. }\end{array}$ & $\begin{array}{l}\text { Penelitian tersebut menambahkan } \\
\text { wawasan peneliti terkait kehidupan umat } \\
\text { beragama di tengger. Manfaatnya untuk } \\
\text { penelitian ini, peneliti bisa melihat } \\
\text { apakah ada pengaruhnya kebijakan } \\
\text { konservasi TNBTS terhadap kehidupan } \\
\text { beragama masyarakat tengger. }\end{array}$ \\
\hline
\end{tabular}

\section{HASIL DAN PEMBAHASAN}

\section{Gambaran Umum Kebijakan Nasional Konservasi Taman Nasional}

Di Indonesia kebijakan nasional terkait penetapan taman nasional tidak bisa lepas dari proses berkembangnya gagasan konservasi di negara-negara maju. Puncak perjalanan gagasan konservasi dalam komunitas internasional yang dipelopori oleh negara-negara barat adalah ketika di Swiss dibentuk International Union for Conservation of Nature and Natural Resources (IUCN. IUCN adalah lembaga konservasi internasional yang memegang peran penting dalam mendiseminasikan gagasan konservasi di berbagai negara di belahan dunia dengan mengkreasikan role model. Hingga bahkan dalam beberapa hal mengkondisikan penyeragaman melalui kriteria, norma dan standar (Dunggio, 2009: 43)

Taman Nasional (TN), khususnya di wilayah Bromo Tengger Semeru, merupakan kawasan pelestarian alam yang mempunyai ekosistem asli, dikelola dengan sistem zonasi dan dimanfaatkan untuk tujuan penelitian, ilmu pengetahuan, pendidikan, menunjang budidaya, budaya, pariwisata dan rekreasi (Profil Taman Nasional Bromo Tengger Semeru, 2010). Taman Nasional di Indonesia dilindungi oleh Undang-undang Nomor 5 Tahun 1990 tentang Konservasi Sumberdaya Alam Hayati dan Ekosistemnya. Kementerian Kehutanan (dalam Budiyanti, 2015) telah menunjuk/ menetapkan 50-unit taman nasional dengan luas 16,4 juta hektar atau 58\% dari luas total kawasan konservasi di Indonesia sampai dengan akhir tahun 2010 kemarin. Sebagian besar kawasan taman nasional tersebut 
menghadapi berbagai permasalahan, seperti perambahan hutan, pemukiman liar, pembalakan, perburuan dan kebakaran, tidak terkecuali TN.BTS. Sementara itu, kondisi taman nasional sangat beragam dari sejarah pembentukan, tujuan pengelolaan, luasan, aksessibilitas, biofisik dan sosekbud masyarakat, kelembagaan pengelola, tingkat capaian pengelolaan, kondisi dan dinamika pembangunan wilayah, dan satus global (Nugroho, 2016).

Penetapan Taman Nasional Bromo Tengger Semeru adalah salah satu upaya yang dilakukan oleh pemerintah dalam menjaga ketersediaan sumber daya alam adalah penetapan suatu kawasan yang memiliki fungsi perlindungan sistem penyangga kehidupan, pengawetan keanekaragaman jenis tumbuhan dan hewan, serta pemanfaatan secara lestari sumber daya alam hayati dan ekosistemnya, yang disebut dengan kawasan pelestarian alam. Taman nasional merupakan salah satu bentuk kawasan pelestarian alam yang dikelola agar mampu memenuhi ketiga fungsi tersebut. Kawasan taman nasional yang ada di Indonesia ada yang peruntukkanya untuk menjaga kawasan pelestarian alam yang berupa kawasan hutan, gunung, satwa dan perairan. Dari penjelasan diatas, maka kawasan TN.BTS yang merupakan kawasan pelestarian alam yang memiliki fungsi perlindungan, pengawetan, dan pemanfaatan secara berkelanjutan dibentuklah balai besar (BB) taman nasional yang bertujuan untuk mengelola dan menjaga fungsi kawasan TN.BTS. (Keputusan Kepala Balai Besar Taman Nasional Bromo Tengger Semeru Nomor: SK. 47 /IV-21/BT.1/2013).

BB-TNBTS memiliki strategi untuk menjaga dan mengelola taman nasional, beberapa kegiatan meliputi: (1) inventarisasi tumbuhan dan satwa endemik, tanaman obat, dan rumput pegunungan, (2) kajian flagship dan fauna (3) updating data populasi tumbuhan dan satwa serta ekosistemnya, (4) pembinaan habitat, (5) Monitoring dan evaluasi satwa dan lain sebagainya (Rencana Strategis Tahun 2015-2019 TNBTS). Namun, dalam pelaksanaanya BB-TNBTS mengalami berbagai dinamika terkait pelestarian hingga pengawasan pengelolaan taman nasional. Jumlah penduduk beberapa desa enclave, salah satunya adalah Desa Ranu Pani, yang semakin bertambah akan meningkatkan tekanan masyarakat terhadap kawasan. Jenis gangguan terhadap kawasan meliputi, perambahan, pencurian kayu hasil hutan non kayu dan perburuan. Kasus perembahan kawasan intensitas kejadiannya cenderung tetap, namun luas lahan yang dirambah cenderung meningkat. Meskipun demikian, upaya penyelesaian kasus perambahan menunjukan kinerja yang baik. Jumlah kasus perambahan yang diselesaikan selama periode tahun 2011-2014 sebanyak 13 kasus, yang melebihi target sebanyak 7 kasus (Nugroho \& Darwiyati, 2016).

\section{Gambaran Umum Tentang Masyarakat Tengger}

Sejak zaman Majapahit dataran tinggi Tengger dikenal sebagai wilayah yang damai, tenteram, dan bahkan rakyatnya terbebas dari membayar pajak yang disebut titileman (Titileman adalah pajak upacara kenegaraan). Jenderal Thomas Stamford Raffles sangat mengagumi orang Tengger. Dalam The History of Java ia mengemukakan bahwa pada saat berkunjung ke tempat yang sejuk itu, ia melihat orang Tengger yang hidup dalam suasana damai, teratur, tertib, jujur, rajin bekerja, dan selalu gembira. Mereka tidak mengenal judi dan candu. Ketika Raffles bertanya tentang perzinahan, perselingkuhan, pencurian, atau jenis-jenis kejahatan lainnya, mereka yang biasa disebut sebagai orang gunung itu menjawab bahwa hal-hal tersebut tidak ditemui di Tengger (Sutarto 1998: 21-37).

Kejujuran dan ketulusan orang Tengger masih dapat dilihat sampai hari ini. Angka kejahatan di desa-desa Tengger pada umumnya hampir selalu nol. Suasana damai, tenteram, aman, dan penuh toleransi yang tercermin dalam kehidupan seharihari orang Tengger dapat dijadikan acuan dalam periode formatif Indonesia modern. Tengger adalah sebuah pusaka saujana (cultural landscape) 
yang apabila dibina dan dikelola dengan benar, eksistensinya akan memberi sumbangan yang lebih berarti bukan hanya bagi dirinya, melainkan juga bagi Indonesia.

Masyarakat Tengger tersebar di banyak desa dibeberapa wilayah kabupaten di Jawa Timur. Desa-desa dalam wilayah 4 kabupaten yang mayoritas penduduknya beragama Hindu dan masih memegang teguh adat-istiadat Tengger. Desa-desa yang dimaksud adalah Ngadas, Jetidak, Wonotoro, Ngadirejo, dan Ngadisari (Kecamatan Sukapura, Kabupaten Probolinggo), Ledokombo, Pandansari, dan Wonokerso (Kecamatan Sumber, Kabupaten Probolinggo), Tosari, Wonokitri, Sedaeng, Ngadiwono, Podokoyo (Kecamatan Tosari, Kabupaten Pasuruan), Keduwung (Kecamatan Puspo, Kabupaten Pasuruan), Ngadas (Kecamatan Poncokusumo, Kabupaten Malang), dan Argosari serta Ranu Pani (Kecamatan Senduro, Kabupaten Lumajang).

Orang Tengger dikenal sebagai petani tradisional yang tangguh, bertempat tinggal berkelompokkelompok di bukit-bukit yang tidak jauh dari lahan pertanian mereka. Suhu udara yang dingin membuat mereka betah bekerja di ladang sejak pagi hingga sore hari. Persentase penduduk yang bermata pencaharian sebagai petani sangat besar, yakni 95\%, sedangkan sebagian kecil dari mereka (5\%) hidup sebagai pegawai negeri, pedagang, buruh, dan usaha jasa. Bidang jasa yang mereka tekuni antara lain menyewakan kuda tunggang untuk para wisatawan, baik dalam maupun luar negeri, menjadi sopir jeep (biasanya miliknya sendiri), dan menyewakan kamar untuk para wisatawan.

Hasil pertanian yang utama adalah sayur mayur, seperti kobis, kentang, wortel, bawang putih, dan bawang prei. Lahan mereka juga cocok untuk tanaman jagung. Pada awalnya jagung adalah makanan pokok orang Tengger. Pada saat ini mereka kurang suka menanam jagung karena nilai ekonominya rendah dan menggantinya dengan sayur-sayuran yang nilai ekonominya tinggi. Meskipun begitu, sebagian lahan pertanian mereka masih ditanami jagung karena tidak semua orang Tengger mengganti makanan pokoknya dengan beras. Hanya saja, untuk memanen jagung, orang Tengger harus menunggu cukup lama, hampir satu tahun. Sampai sekarang nasi aron Tengger (nasi jagung) masih tercatat sebagai makanan tradisional dalam khazanah kuliner Nusantara.

Suku Tengger adalah sebuah suku yang berada di sekitar Gunung Bromo. Penduduknya bertempat tinggal di sekitar daerah Kabupaten Pasuruan, Kabupaten Probolinggo, dan Kabupaten Malang. Suku yang paling dekat dengan suku Tengger adalah suku Jawa akan tetapi ada perbedaan dari keduanya, terutama pada bentuk kebudayaannya. Kurniasudar (2015) menyatakan bahwa Luas daerah Tengger kurang lebih 40 km dari Utara ke Selatan dan 20-30 km dari Timur ke Barat, di atas ketinggian antara 1000m-3675m. Kaldera Tengger adalah lautan pasir terluas, terletidak pada ketinggian 2300M, dengan panjang 5-10 km. Kawah Gunung Bromo, dengan ketinggian 2392m dan masih aktif. Di sebelah Selatan menjulang puncak Gunung Semeru dengan ketinggan 3676.

Suku Tengger yang beragama Hindu hidup di wilayah Gunung Bromo, Kabupaten Probolinggo, Jawa Timur. Pada tahun 1985 jumlah mereka sekitar 40 ribu. Ada banyak makna yang dikandung dari kata Tengger. Secara etimologis, Tengger berarti berdiri tegak, diam tanpa bergerak (Jawa). Bila dikaitkan dengan adat dan kepercayaan, arti tengger adalah tengering budi luhurartinya tanda bahwa warganya memiliki budi luhur. Makna lainnya adalah daerah pegunungan. Tengger memang berada pada lereng Pegunungan Tengger dan Semeru.

Ada pula pengaitan Tengger dengan mitos masyarakat tentang suami istri cikal bakal penghuni wilayah Tengger, yakni Rara Anteng dan Joko Seger. Selain itu, di wilayah ini terdapat pula cerita tentang Sejarah Gunung Batok, Lautan Pasir, Kawah Bromo. Kisah lainnya menyangkut Ajisaka aksara Jawa, juga kisah Klambi Antrakusuma. Sejarah Tengger dari sisi ilmiah erat kaitannya dengan Prasasti Tengger bertahun 851 Saka (929 Masehi), diperkuat Prasasti Penanjakan bertahun 1324 
Saka (1402 Masehi) (Savitri, 2010). Disebutkan sebuah desa bernama Wandalit yang terletak di pegunungan Tengger dihuni oleh Hulun Hyang (hamba Tuhan = orang-orang yang taat beragama) yang daerah sekitarnya disebut hila-hila (Suci). Karena itulah kawasan Tengger merupakan tanah perdikan istimewa yang dibebaskan dari pembayaran pajak oleh pusat pemerintahan di Majapahit. Masyarakat Tengger dikenal luas beragama Hindu, berpadu dengan kepercayaan tradisional. Hindu masyarakat Tengger berbeda dengan Hindu di Bali. Perbedaannya antara lain, Hindu Tengger tidak mengenal ngaben sebagai upacara kematian sebagaimana di Bali.

Masyarakat Tengger adalah masyarakat yang mayoritas warganya memiliki latar belakang pekerjaan sebagai petani. Pada perkembangannya, masyarakat Tengger melakukan pemotongan pohon-pohon untuk mengosongkan lahan yang nantinya digunakan sebagai lahan pertanian (Nugroho, 2016). Dampaknya dibeberapa tempat, ada bukit yang tidak bertingkat dan juga sangat curam. Jadi masyarakat Tengger menghadapi masalah erosi yang sangat serius. Jalan-jalan yang dimiliki oleh masyarakat Tengger kebanyakan ditutupi dengan pasir dan di banyak tempat mencapai kedalaman sepuluh senti. Hal yang dianggap sepele ini terjadi disalah satu desa masyarakat Tengger, yaitu Desa Ranupani. Selama musim kemarau dan angin kencang, pasir akan menghembuskan ke danau Ranupani. Menurut Bapak Sarmin, (salah satu masyarakat Tengger yang menjadi informan) dari dua puluh tahun yang lalu, kedalaman tengah danau Ranupani adalah dua puluh meter, sekarang tengah danau adalah kedalaman sekitar tujuh meter.

Pada perkembangannya, secara budaya orang Tengger telah terkepung oleh saudarasaudaranya, orang ngare, yang telah mengidap 'virus' kapitalisme global. Arus modernisasi tersebut menjalar melalui produk-produk seperti radio, televisi, video, VCD player, internet yang menayangkan kemewahan, pembunuhan, kekerasan, kebrutalan erotika dan pornografi, gosip dan berbagai macam kasak-kusuk. Untungnya, kawasan Tengger yang secara fisik telah disesali sebagai devastated area (kawasan yang rusak) oleh para pecinta lingkungan hidup, secara budaya masih terselamatkan.

Mereka masih bertahan sebagai masyarakat agraris yang belum terjebak dalam budaya konsumeristik, materialistik, dan hedonistik. Sampai kapan mereka mampu bertahan, semuanya akan tergantung kepada para pewaris aktif tradisi Tengger, yaitu para dukun Tengger (Sutarto, 1999). Uraian di atas menunjukkan, meskipun kawasan Tengger mendapat tekanan baik yang berdimensi ekonomi, agama, dan budaya, para dukun Tengger masih tetap berperan sebagai pewaris aktif tradisi Walandhit dan Majapahit. Itu berarti bahwa mereka masih melaksanakan peribadatan sesuai dengan kepercayaan mereka dan menggunakan alat-alat ritual yang bercitra Hindu seperti Gentha, Kropak, Prasen (tempat air suci) dan Prapen (tempat api dan kemenyan), dan mengenakan sampet (selendang, yang biasa dipakai oleh pendeta Indu pada zaman Majapahit).

Mereka juga masih memuliakan Gunung Bromo dan gunung-gunung lain di sekitarnya. Orang Tengger, meskipun menyebut dirinya orang Gunung, tidak buta politik. Meskipun begitu, mereka tidak membutuhkan media politik untuk meraih status sosial, prestise, atau akses menuju kekuasaan dan oleh karenanya tidak pernah terlibat konflik politik secara berarti (Faridah, 2013). Mereka, meskipun sudah mengenyam pendidikan di perguruan tinggi, lebih memilih sebagai petani daripada profesi lain. Semangat pluralisme yang diejawantahkan melalui sikap budaya dan agama membuat orang Tengger terbebas dari konflik yang berdimensi etnis dan keagamaan.

Imajinasi dan eksotisme massal modern yang ditangkap melalui media elektronik hanya membuat orang Tengger terhenyak dan terkagum-kagum tetapi belum terpengaruh oleh gaya hidup orangorang atau tokoh-tokoh yang mereka lihat melalui media tersebut (Batoro, 2013). Sebagian besar orang Tengger masih memposisikan dirinya sebagai wong gunung (orang yang tinggal di gunung) yang berbeda dari wong ngare (orang yang bertempat tinggal di tempat rata, di dataran rendah atau di kota). Di mata wong gunung, wong ngare itu penuh kesenjangan, banyak yang kaya, tetapi 
banyak pula yang miskin, tidak memiliki tanah. Menurut wong gunung, wong ngare itu suka menyendiri dan membedakan status. Wong ngare sering menilai seseorang dari pangkatnya. Sebaliknya, bagi wong gunung, semua orang dianggap sama (padha) dan satu keturunaan (sakturunan). Karena padha dan sakturunan, maka dalam kehidupan wong gunung tidak dikenal istilah kongkon (menyuruh) orang lain. Istilah yang dikenal adalah bantu kuwat yakni memberi bantuan kepada tetangganya karena beban pekerjaan tetangga tersebut terlalu berat. (Hefner, 1990:14)

\section{Konservasi Lahan Di Bromo Tengger Semeru Beserta Masalahnya}

Meski membatasi aktivitas dan daya jelajah masyarakat adat Tengger, keberadaan Taman Nasional Bromo Tengger Semeru membuka peluang pendapatan baru bagi mereka, terutama dalam bidang pariwisata. Sebab, salah satu fungsi taman nasional adalah fungsi wisata, selain fungsi perlindungan dan pelestarian (konservasi) serta pendidikan. Memang, sudah sejak sekitar 1940-an para wisatawan mulai sering mengunjungi Bromo-Tengger, meskipun jumlah dan kekerapannya belum sebanyak dan sesering saat ini, ketika Bromo-Tengger secara resmi dijadikan tujuan wisata oleh pemerintah dengan menetapkannya sebagai Taman Nasional. (Hefner, 1985)

Banyak orang Tengger yang menyediakan rumah mereka untuk digunakan sebagai penginapan bagi para wisatawan, menjadi porter, menyewakan kuda, juga mengelola jeep dan sepeda motor sebagai sarana transportasi wisata. Ada yang melakukan pelayanan wisata itu secara paruh waktu, penambah kegiatan selain bertani di ladang atau pekerjaan lain. Ada yang melakukannya sebagai profesi utama yang terakhir ini kebanyakan bekerja di hotel dan penginapan di sekitar BromoTengger (Mujanah \& Andayani, 2016).

Akan tetapi dibalik setiap kegiatan wisata yang menawarkan tambahan pendapatan dan janjijanji masa depan ekonomi yang lebih baik bagi masyarakat Tengger, tersimpan potensi masalah baru, yakni percepatan kerusakan wilayah keramat didaerah Tengger dan berkembangnya isu kerusakan lingkungan yang senantiasa menyertainya (Nugroho \& Darwiati, 2016). Dilema inilah yang dialami oleh sektor pariwisata Bromo-Tengger. Pada satu sisi, meningkatnya pengunjung berarti meningkatnya pendapatan masyarakat dari sektor wisata. Pada saat yang sama, di sisi lain, kerapnya kunjungan itu, jika tidak dikelola dengan benar, berpotensi merusak obyek wisata, tanah adat, wilayah keramat, ekosistem penting, yang pada gilirannya dapat memusnahkan bukan saja pendapatan ekonomi dari sektor wisata, tetapi juga meruntuhkan bangunan sosial dan identitas masyarakat, karena efek domino dari rusaknya lingkungan dan simbol-simbol religi masyarakat Tengger (Smith, 2005)

Pada Intinya, pada satu sisi, Masyarakat Tengger tidak akan bisa dipisah atau terpisah dari Gunung Bromo dan Tengger serta Segoro Wedhi dan gunung-gunung sekitarnya, sebab situs-situs itu merupakan pusat-pu-sat dari kehidupan mereka, dengan Bromo-Tengger sebagai inti kehidupannya. Pada sisi lain, kawasan Bromo-Tengger itu demikian indah, pastilah akan mengundang banyak wisatawan lokal dan mancanegara untuk berdatangan mengunjunginya. Semakin banyak orang mengunjungi Bromo-Tengger, berarti makin meningkatnya pendapatan tambahan bagi Masyarakat Tengger yang mengelola wisata. Namun, semakin marak dan bertambahnya kunjungan wisata ke Bromo-Tengger, jika tidak dikelola dengan benar, dapat merusak Gunung Bromo, Tengger, Segoro Wedhi, Pananjakan, dan kawasan sekitarnya, yang berarti juga rusaknya pusat-pusat kosmos Wong Tengger. (Hikayat Wong Tengger, 2013:13)

Kerugian yang akan dihadapi Masyarakat Tengger bukan saja hilangnya keuntungan ekonomi dari kegiatan wisata, tetapi juga runtuhnya identitas Wong Tengger karena musnahnya situs-situs 
keramat dan wilayah adat mere-ka. Bencana sosial itu tidak boleh terjadi, karena dampak langsung dan tidak langsungnya tentu tidak hanya akan menimpa masyarakat Tengger saja: apa artinya menjadi Wong Tengger tanpa Gunung Bromo, Tengger, Segoro Wedhi, dan kawasan luas sekitarnya? Lebih lagi, rusaknya situs-situs keramat Tengger itu sama dengan hancurnya ekosistem yang dikandungnya dan itu berarti bencana lingkungan yang tidak terbayangkan dahsyatnya.

Di atas kertas, pihak taman nasional tidak akan mampu mengelola kawasan Bromo-TenggerSemeru sendirian. Di antaranya karena sampai kini belum juga ditemukan sistem yang dianggap mapan untuk mengurusi dan mengatasi berbagai persoalan menyangkut pengelolaan taman nasional. Karenanya, tidak bijak rasanya menyerahkan urusan mahapenting ini hanya kepada suatu badan pengelola yang bahkan belum menemukan sistem pengelolaan yang andal.

Sejak mula pertama taman nasional lahir di Indonesia pada 1980, konsep pengelolaan taman nasional senantiasa berubah-ubah (Dendang, 2016). Paradigma pengelolaan yang mula-mula diterapkan adalah pendekatan perlindungan (security approach), yang mengutamakan kepentingan pelestarian (konservasi) di atas berbagai kepentingan lainnya. Paradigma ini menafikan peran masyarakat lokal berikut kearifan-kearifan tradisional yang telah berabad-abad mereka yakini dan terapkan (Hikayat Wong Tengger, 2013:16)

Pada 1994, konsep pengelolaannya mulai mengakui keberadaan masyarakat sekitar taman nasional dan kearifan mereka. Menyusul kemudian, pada 2004, peran serta para pemangku kepentingan (stidakeholders) taman nasional diupayakan muncul dalam suatu kerja sama (kolaborasi) pengelolaan. Hanya saja, cara pandang yang digunakan masih menganggap masyarakat, termasuk masyarakat adat, sebatas sebagai obyek pengelolaan belaka (Widyaprakosa, 1994). Kebijakan pengelolaan taman nasional model, dengan ditetapkannya 20 taman nasional sebagai taman nasional mandiri kemudian lahir pada tahun 2006. Namun, kebijakan itu tidak kunjung diikuti dengan pedoman pelaksanaannya, sehingga sampai saat ini masih belum ada taman nasional yang mampu mandiri dalam biaya operasionalnya.

Kemudian, diterbitkanlah kebijakan taman nasional berbasis resor: membagi kawasan taman nasional menjadi area-area berluas tertentu yang relatif mudah dikelola (manageable), mencontoh sistem pengelolaan hutan yang diterapkan Perum Perhutani. Apakah kemudian perbaikan-perbaikan terus-menerus terhadap konsep-konsep pengelolaan itu dapat mengatasi problem-problem taman nasional? Tampaknya tidak secepat itu. Di beberapa taman nasional yang serupa (namun jelas tidak sama) kondisi wilayah dan sifat wisatanya, misalnya Bromo-Tengger-Semeru dibanding GedePangrango dan Halimun-Salak, problematikanya tetap tidak berubah dari masa ke masa: pembalakan liar berskala lumayan besar (komersial) sampai yang kecil-kecil "sekadar untuk memenuhi ke-butuhan penduduk lokal”; sampah di pusat-pusat wisata; pencemaran sumber-sumber air bersih; membludak-nya pengunjung; "kurangnya” personil di tingkat resort, yang dampaknya salah satunya adalah jarangnya patroli lapangan; vandalisme pengunjung terhadap fasilitas wisata; kurangnya wibawa pengelola taman nasional di mata wisata-wan; dan sebagainya. Masalah-masalah itu seperti tidak tersentuh, dan karenanya seperti sangat sulit diatasi.

Bagaimana pun, pengelola taman nasional tidak dapat sepenuhnya disalahkan atas tidak kunjung berkurangnya segala masalah perlindungan dan pelestarian kawasan konservasi itu. Sebab, posisi para pengelola taman nasional itu, sebagai Unit Pelaksana Teknis, mirip serdadu yang dipaksa maju ke garda depan tanpa bekal amunisi yang cukup. Sebagai salah satu contoh: dari sekian rupiah hasil penjualan retribusi/karcis masuk kawasan taman nasional, berapa banyak yang kembali ke kas taman nasional? Dalam kasus TN.BTS dan serupa saja kasusnya dengan taman nasional lain hanya $5 \%$ saja yang diterima taman nasional. 
Prosentase yang sama, 5\%, disetorkan ke Badan Koordinasi Wilayah Pemerintahan dan Pembangunan III. Prosentase terbesar, 40\%, disetorkan ke Pemerintah Kabupaten Probolinggo, Pasuruan, Malang, dan Lumajang, masing-masing mendapat porsi yang berbeda-beda, proporsional terhadap penerimaan retribusi dari pintu-pintu masuk di setiap Pemkab itu. Pemerintah Provinsi Jawa Timur mendapat jatah 20\%. Kementerian Kehutanan mendapat 15\%; Begitu juga Kas Negara (Bendahara Umum Negara), mendapat 15\%. Pendapatan 5\% untuk pengelola taman nasional dari karcis masuk itu merupakan kebijakan lokal Gubernur Jawa Timur, bukan ketetapan Kementerian Kehutanan. Jadi, kecil sekali porsi yang didapat Balai Besar (BB) TN-BTS dari hasil wisata di Bromo-Tengger-Semeru, padahal pihak taman nasionalah pengelola sekaligus pencetak karcis masuk kawasan wisata.

\section{Peran TNBTS untuk menanggulangi masalah konservasi lahan di Bromo Tengger Semeru}

Di antara para pemangku kepentingan (stakeholders) Taman Nasional Bromo-TenggerSemeru, yang akan paling langsung terkena dampak kerusakan kawasan Bromo-Tengger-Semeru dan yang akan paling parah menderita adalah masyarakat adat Tengger, yang telah berabad-abad menetap di sekitar Taman Nasional, yang wilayah adat mereka berada dalam kawasan Taman Nasional. Merekalah yang mesti-nya berkepentingan paling besar atas lestarinya kawasan BromoTengger-Semeru, hingga karenanya upaya-upaya pemberdayaan-aktif mereka dalam menjaga kelestarian Kawasan Taman Nasional perlu diprioritaskan.

Pemberdayaan-aktif itu artinya melibatkan masyarakat adat Tengger da-lam perencanaan, pelaksanaan, penerimaan manfaat, juga dalam proses pemantauan (monitoring) dan evaluasi pengelolaan Taman Nasional Bromo-Tengger-Semeru. Pada tahap perencanaan, dapat saja dilakukan konsultasi publik oleh Taman Nasional kepada masyarakat Tengger. Pada tahap pelaksanaan, masyarakat bisa didorong untuk proaktif menjaga kelestarian kawasan konservasi, karena lestarinya Taman Nasional identik dengan lestarinya wilayah adat mereka. Terkait penerimaan manfaat, keberdayaan masyarakat dapat dioptimalkan dalam bidang pariwisata, pertanian, dan pengolahan hasil hutan tertentu tanpa perlu menyalahi prinsip-prinsip pelestarian. Pemantauan dan evaluasi dapat diwujudkan lewat temukoordinasi rutin misalnya bulanan atau per tiga bulan antara pemerintah (BBTNBTS) dengan masyarakat Tengger. Tentu saja upaya pemberdayaan masyarakat itu bukan proses mudah, namun konsep pengelolaan kolaboratif yang ditetapkan pada 1994 dan 2004 dapat dijadikan titik tolak. Hanya saja, pemerintah pusat (Kementerian Kehutanan) dan terutama Unit Pelaksana Teknis BB-TN-BTS perlu secara radikal mengubah cara pandang mereka yang, diakui atau tidak, masih menganggap masyarakat, utamanya masyarakat adat di sekitar Taman Nasional, sebatas sebagai obyek pengelolaan belaka.

Pada sisi masyarakat, upaya pemberdayaan itu akan relatif mudah dilaksanakan karena, pertama, masyarakat Tengger punya simpul-simpul “komando” dalam pranata sosial mereka, yakni para dukun pandhita Tengger yang sangat mereka hormati petuah dan titahnya (Setiawan, 2012). Hampir dapat dipastikan bahwa para pemimpin adat Tengger itu akan antusias untuk benar-benar dilibatkan dalam pengelolaan Taman Nasional dan masyarakat akan mengamini fatwa para pemimpin adat mereka. Bahkan bisa jadi "political will” itulah yang mereka tunggu-tunggu selama ini: niat kuat pemerintah untuk melibatkan masyarakat Tengger, memosisikan mereka sebagai salah satu pelaku dalam mengelola kawasan Bromo-Tengger-Semeru yang juga merupakan tanah adat mereka.

Kedua, perlu diingat, sejarah panjang masyarakat Tengger sejak zaman penjajahan sampai kini, seperti telah diuraikan di atas, adalah sejarah peminggiran (marginalisasi) dan pertarungan untuk 
menghe-gemoni, bahkan menguasai, masyarakat Tengger dalam berbagai aspek kehidupan mereka oleh berbagai kekuatan dan kepentingan dari luar Tengger. Sedemikian sengit dan kompleksnya "gempuran" itu, sampai-sampai bisa dikatakan bahwa masyarakat Tengger mengalami krisis identitas. Oleh sebab itu, upaya memosisikan mereka sebagai pelaku aktif pembangunan dalam pengelolaan kolaboratif BB-TNBTS akan diterima dengan baik. Sistem pengelolaan kolaboratif itu perlu perubahan mendasar (radikal), mulai dari penggeseran bahkan pengubahan paradigma (misalnya, masyarakat pinggiran hutan itu bukan kumpulan orang yang tidak bisa diajak bekerja sama dalam sistem “modern”) dan mengubah paradigma itu hampir sama sulitnya dengan mengajak orang berganti keyakinan.

Upaya mendorong kesiapan masyarakat dengan meningkatkan keberdayaan mereka itu dapat diselenggarakan melalui tiga langkah yang perlu dilaksanakan secara bersamaan (simultan): pertama, menguatkan identitas sosial Wong Tengger; kedua, memfasilitasi penerapan Pendidikan Kritis bagi masyarakat Tengger tua-muda; dan ketiga, memfasilitasi pembangunan sarana dan prasarana yang dibutuhkan masyarakat Tengger dan Taman Nasional Bromo-Tengger-Semeru untukkelangsungan upaya pelestarian Taman Nasional.

Penguatan identitassosialWong Tengger perlu dilakukan, mengingat telah terjadinya dan masih berlangsungnya krisis identitas masyarakat Tengger akibat berbagai gempuran budaya "asing” terhadap sistem budaya dan pranata sosial masyarakat Tengger (Haliim, 2017). Penyelenggaraan Pendidikan Kritisyang bercorak partisipatif, tidak menggurui, dan dialogis diperlukan untuk memperkukuh proses penguatan identitas sosial masyarakat Tengger di atas. Pendidikan Kritis adalah madzhab pendidikan yang bertujuan memberdayakan dan membebaskan pembelajarnya, masyarakat. Konsep pendidikan ini mencita-citakan perubahan sosial: terwujudnya masyarakat adil dan demokratis, tanpa eksploitasi dan penindasan.

Dalam jangka pendek, ia mendorong proses pemanusiaan kembali (humanisasi), berupaya memulangkan manusia kepada fitrahnya, mengembalikan kondisi kemanusiaan mereka yang terjerat krisis sosial akibat dominasi peran dan hegemoni pelaku-pelaku sosial lain kepada kesejatian diri mereka yang merdeka. Proses Pendidikan Kritis bertolak dari kesadaran kritis manusia, belajar dari kenyataan atau pengalaman, mengantarkan individu-individu pembelajarnya untuk memecahkan masalah-masalah eksistensial mereka secara bersama-sama. Mendukung dua langkah peningkatan keberdayaan di atas diperlukan pembangunan sarana dan prasarana penunjang upaya pelestarian Taman Nasional perlu dilaksanakan, tentu dengan mengacu kepada Master Plan Taman Nasional dan skala prioritas. Misalnya, dalam jangka pendek, pemindahan (penetapan) jalur khusus kendaraan di Segoro Wedhi terasa sangat mendesak untuk segera dilaksanakan, agar dampak negatif dari liarnya lalu-lintas kendaraan di lautan pasir Bromo-Tengger itu dapat segera diantisipasi sedini mungkin.

Dari segi infrastruktur, renovasi infrastruktur Penanjakan-1 yang sejak lama telah menjadi fokus kajian pengelola BB-TNBTS terkait carrying capacity-nya, yakni batas maksimal daya tampung lokasi-pandang yang menjadi pu-sat kerumunan para wisatawan untuk menikmati panorama matahari terbit. Jika masalah daya tampung lokasi-pandang Penanjakan-1 itu tidak segera dicarikan solusinya, bahaya longsor berpotensi terjadi akibat kelebihan beban kerumunan wisatawan (Manik, 2013). Dampaknya bukan saja rusaknya ekosistem, tetapi juga hilangnya lokasi pandang paling strategis untuk menikmati sunrise: lenyapnya sarana penting penunjang ekowisata.

\section{E. PENUTUP}

Masyarakat Tengger, khususnya para penduduk Desa Ranu Pani merupakan Desa enclave (desa yang berada di dalam kawasan taman nasional) yang ada di Taman Nasional Bromo Tengger 
Semeru. Selain itu masyarakat tengger juga memiliki latar belakang pekerjaan sebagai petani. Masyarakat Tengger juga melakukan pemotongan pohon-pohon untuk mengosongkan lahan yang nantinya digunakan sebagai lahan pertanian. Dampaknya, negatif dibeberapa tempat, ada bukit yang menjadi sangat curam. Perilaku tersebutlah yang dinilai penulis menjadi awal mula permasalahan konservasi lahan didaerah TN.BTS.

Selain itu, permasalahan konservasi lahan TN.BTS juga berasal dari sektor wisata. Masyarakat Tengger tidak akan bisa dipisah atau terpisah dari Gunung Bromo dan Tenggerdan gunung-gunung sekitarnya. Karena situs-situs itu merupakan pusat-pusat dari kehidupan. Di lain sisi, Keindahan kawasan Bromo-Tengger tidak terelakkan lagi. Dampaknya, pastilah akan mengundang banyak wisatawan lokal dan mancanegara untuk berdatangan mengunjunginya. Maka, semakin banyak pengunjung Bromo-Tengger, berarti makin meningkatnya penghasilan tambahan bagi Masyarakat Tengger. Namun, semakin maraknya kunjungan wisata ke Bromo-Tengger, jika tidak dikelola dengan baik dan benar, Kerusakan alam akan dialami Gunung Bromo, Tengger, Segoro Wedhi, Pananjakan, dan kawasan sekitarnya, yang berarti juga rusaknya pu-sat-pusat kehidupan dari masyarakat Tengger (Astriyantika, 2016).

Masyarakat Tengger menghadapi, bukan saja hilangnya keuntungan ekonomi dari kegiatan wisata, tetapi juga runtuhnya identitas mereka karena rusak atau musnahnya situs-situs keramat di wilayah adat mereka. Masalah sosial ini tidak boleh dibiarkan, karena dampak langsung dan tidaklangsungnya tentu akan menimpa masyarakat Tengger. Apa artinya menjadi Wong Tengger tanpa Gunung Bromo-Tengger, dan kawasan luas sekitarnya? Rusaknya situs-situs keramat Bromo-Tengger juga bisa diartikan sama dengan hancurnya ekosistem dan itu berarti bencana lingkungan yang sangat luar biasa. Namun BB-TN.BTS sebagai pihak pengelola kawasan Bromo-Tengger-Semeru tidak bisa berkerja sendirian. Karena memang sam-pai hari ini belum juga ditemukan sistem yang mampu untuk mengurusi dan mengatasi berbagai permasalahan menyangkut pengelolaan TN.BTS.karenanya upaya-upaya pemberdayaan aktif para masyarakat Tengger dalam menjaga kelestarian Kawasan Taman Nasional perlu diprioritaskan (Mujanah, S, Ratnawati, T \& Andayani, 2016).

Pemberdayaan aktif itu artinya melibatkan masyarakat Tengger dalam perencanaan, pelaksanaan, penerimaan manfaat, juga dalam proses pemantauandan evaluasi pengelolaan Taman Nasional Bromo-Tengger-Semeru (Khususnya Masyarakat Adat Tengger). Pada tahap perencanaan, dapat saja dilakukan konsultasi publik oleh pihak TN.BTS kepada masyarakat Tengger. Pada tahap pelaksanaan, masyarakat Tengger bisa didorong untuk proaktif menjaga kawasan konservasi. Dengan lestarinya Taman Nasional identik dengan lestarinya wilayah adat mereka. Peberdayaan masyarakat dapat dioptimalkan dalam bidang pariwisata, pertanian, dan pengolahan hasil hutan tertentu tanpa perlu menyalahi prinsip-prinsip pelestarian. Pemantauan dan evaluasi dapat diwujudkan lewat koordinasi rutin antara pemerintah (BB-TNBTS) dengan masyarakat Tengger.

Cara meningkatkan pemberdayaan dapat diselenggarakan melalui tiga langkah yang perlu dilaksanakan secara bersamaan: pertama, menguatkan identitas sosial Wong Tengger, contohnya pemerintah berserta masyarakat tengger bersama-sama melakukan musyawarah untuk menciptakan Branding masyarakat tengger untuk di komunikasikan kepada masyarakat luar tengger. Tujuannya adalah agar masyarakat luar Tengger mengetahui lebih jauh bagaimana kehidupan sosial masyarakat tengger, tidak hanya keindahan panorama didaerah tengger saja; kedua, memfasilitasi penerapan Pendidikan Kritis bagi masyarakat Tengger, pendidikan kritis yang dmaksud adalah memberikan pemahaman kepada masyarakat desa tentang pentingnya konservasi lahan disekitar TNBTS; dan ketiga, mem-fasilitasi pembangunan sarana dan prasarana yang dibutuhkan masyarakat Tengger dan TN.BTS untuk kelangsungan upaya pelestarian Taman Nasional. 


\section{DAFTAR PUSTAKA}

\section{DAFTAR PUSTAKA WIMMI}

Andersen, E. James. (1997). Public Policy-Making, Third Edition. New York: Holt Rinchart Winston.

Astriyantika, M. (2016). Studi Konservasi Sumberdaya Alam Hayati pada Masyarakat Tengger di Resort Ranu Pani, Taman Nasional Bromo Tengger Semeru. Media Konservasi, 19 (1).

Batoro, J. (2013). Pengetahuan Tentang Tumbuhan Masyarakat Tengger di Bromo Tengger Semeru Jawa Timur. WACANA, Jurnal Sosial dan Humaniora, 14 (1), 1-10.

Budiyanti, S. (2015). Analisis Deskriptif Aaktifitas dan Potensi Komunitas Desa ‘Enclave’ Ranu Pani Pada Zona Pemanfaatan Tradisional, Kecamatan Senduro, Kab. Lumajang, Wilayah Taman Nasional Bromo Tengger Semeru (TNBTS). Dimensi, 8 (2).

Dendang, D. (2016). Keragaman Kupu-Kupu di Resort Selabintana Taman Nasional Gunung Gede Pangrango, Jawa Barat. Jurnal Penelitian Hutan dan Konservasi Alam, 6 (1), 25-36.

Dunggio, Iswan dan Hendra Gunawan. (2009). Telaah Sejarah Kebijakan Pengelolaan Taman Nasional di Indonesia. Jurnal Analitis Kebijakan Kehutanan, Vol. 6, No. 1, April 2009.

East Java Departement of Tourism, art and Culture Service. (2002). Bromo Tengger Semeru National Park. (2010). Profil Taman Nasional Bromo Tengger Semeru.

Esmara, H. (2010). Perencanaan dan Pembangunan di Indonesia. Jakarta: Gramedia Pustaka Utama.

Faridah, Ika F. (2013). Toleransi Antarumat Beragama Masyarakat Perumahan. Jurnal Komunitas, 5 (1), 51-69.

Haliim, W. (2017). Identitas Wong Tengger Masyarakat Desa Ngadas: Refleksi Kebangsaan Atas Degradasi Identitas dan Persatuan Nasional Indonesia. Proceeding AMIPEC, 2(2).

Hefner, Robert. (1990). The Political Economy on Mountain Java: In Interpretive History. University of California Press: Barkeley.

Hefner, Robert. (1985). Hindu Javanese, Tengger Tradition and Islam. Princeton University Press: Princeton.

Jembatan Tiga. (2013). Hikayat Wong Tengger: Pentingnya Meningkatkan Keberdayaan Masyarakat Tengger Balai Besar Taman Nasional Bromo Tengger Semeru untuk Melestarikan Kawasan Konservasi. Available online at http://jembatantiga.com/wpcontent/uploads/Pemberdayaan-Masyarakat-Tengger-untuk-Konservasi-TN-BromoTengger-Semeru.pdf.

Keputusan Kepala Balai Besar Taman Nasional Bromo Tengger Semeru, Nomor: SK. 47/IV-21/ BT.1/2013, Tentang Petunjuk Teknis Standar Operasional Prosedur Pendakian Gunung Semeru di Taman Nasional Bromo Tengger Semeru.

Kurniasudar. "SUKU TENGGER” Di akses pada tanggal 05 Desember 2017, dari: http:// kurniasudiar.wordpress.com/2013/05/06/sukuTengger

Manik, T. R., Adrianto, D. W., \& Subagiyo, A. (2013). Kajian Pengembangan Kawasan Agropolitan Seroja Kabupaten Lumajang. Jurnal Tata Kota dan Daerah, 5 (1), 65-76. 
Miles, Hubberman dan Saldana. (2014). Qualitative Data Analysis: A Methods Sourcebook. United States of America: Sage Publications.

Moelong, Lexy. (2002). Metodologi Penelitian Kualitatif. Bandung: PT. Remaja Rosdakarya.

Mujanah, S., Ratnawati, T., \& Andayani, S. (2016). Strategi Pengembangan Desa Wisata di Kawasan Hinterland Gunung Bromo Jawa Timur. JHP17: Jurnal Hasil Penelitian, 1(01).

Nugroho, A. W., \& Darwiati, W. (2016). Studi Daerah Rawan Gangguan Taman Nasional Bromo Tengger Semeru dan Desa Sekitarnya. Jurnal Penelitian Hutan dan Konservasi Alam, 4 (1), 1-12.

Nugroho, Riant. (2014). Public Policy. Jakarta: Elex Media Komputindo.

Savitri, Alpha. (2010). Sejarah, Agama, dan Tradisi Suku Tengger Gunung Bromo. E-Book, Februari 2010. Di akses pada tanggal 28 Desember 2017, dari: http:// wartawarga.gunadarma.ac.id/wp-content/uploads/2010/02/sejarah Agama Tradisi Tengger Bromo_Alpha Savitri_OK.pdf

Setiawan, I. (2012). Perempuan di Balik Kabut Bromo: Membaca Peran Aktif Perempuan Tengger dalam Kehidupan Rumah Tangga dan Masyarakat. Jurnal Humaniora, 20 (2), 136-148.

Smith, Nancy. (2005). Masyarakat Tengger dalam Sejarah Nasional Indonesia. National Science Foundation: USA.

Surat Keputusan Menteri Kehutanan Nomor: 6186/Kpts-II/2002, Tentang Pengelolaan Taman Nasional Bromo Tengger Semeru.

Surat Keputusan Menteri Kehutanan Nomor: 178/Menhut-II/2005, Tentang Pengelolaandan Penetapan Balai Besar Taman Nasional Bromo Tengger Semeru.

Sutarto. (1998). Tinjauan Historis dan Sosio-kultural Orang Tengger. Majalah Argapura, Vol. 18 No. 1 dan 2.

Sutarto. (1999). Komunitas Lokal dalam Perspektif Perubahan Sosial Budaya: Kasus Tengger. Makalah dalam Simposium Nasional dalam Rangka Lustrum VII Universitas Jember.

Syukur, Abdullah. (1987). Study Implementasi Latar Belakang Konsep Pendekatan dan Relevansinya Dalam Pembangunan. Makassar: Persadi.

Tachjan. (2006). Implementasi Kebijakan Publik. AIPI: Bandung.

Widyaprakosa, Simanhadi. (1994). Masyarakat Tengger, Latar Belakang Daerah Taman Nasional Bromo. Kanisius: Jakarta. 